\title{
Immunolocalization of aromatase P450 in the epididymis of Podarcis sicula and Rattus rattus
}

\author{
Luigi Rosati, Marina Prisco, Mariana Di Lorenzo, Maria De Falco, Piero Andreuccetti \\ Department of Biology, University of Naples Federico II, Italy
}

\begin{abstract}
The goal of this study was to evaluate P450 aromatase localization in the epididymis of two different vertebrates: the lizard Podarcis sicula, a seasonal breeder, and Rattus rattus, a continuous breeder. P450 aromatase is a key enzyme involved in the local control of spermatogenesis and steroidogenesis and we proved for the first time that this enzyme is represented in the epididymis of both $P$. sicula and $R$. rattus. In details, P450 aromatase was well represented in epithelial and myoid cells and in the connective tissue of $P$. sicula epididymis during the reproductive period; instead, during autumnal resumption this enzyme was absent in the connective tissue. During the non-reproductive period, P450 aromatase was localized only in myoid cells of $P$. sicula epididymis, whereas in $R$. rattus it was localized both in myoid cells and connective tissue. Our findings, the first on the epididymis aromatase localization in the vertebrates, suggest a possible role of P450 aromatase in the control of male genital tract function, particularly in sperm maturation.
\end{abstract}

Key words: P450 aromatase; 17ß-estradiol; reproduction; epididymis; vertebrates.

This paper is dedicated to Piero Andreuccetti, who greatly contributed to the work herein described. Magister vitae et scientiarum and wonderful colleague and mentor, he died suddenly on September 28, 2019.

Correspondence: Luigi Rosati, Department of Biology, University of Naples Federico II, Via Cintia 21, 80126 Naples, Italy. E-mail: luigi.rosati@unina.it

Contributions: All the authors made a substantive intellectual contribution, performed part of the experiments, and read and approved the final version of the manuscript. All the authors have read and approved the final version of the manuscript and agreed to be accountable for all aspects of the work. First and second authors equally contributed to this work.

Conflict of interest: The authors declare that they have no competing interests, and all authors confirm accuracy.

Availability of data and materials: All data generated or analyzed during this study are included in this published article.

Ethical Approval: The animal use protocol listed below has been reviewed and approved by the Ministry of Health of the Italian Government. 


\section{Introduction}

It is well known that androgens and gonadotropins play crucial role in spermatogenesis, and in the development and function of the male reproductive system. ${ }^{1}$ However, in the last 10 years it has been shown that also estrogens, for long time regarded as typically female hormones, are involved in the regulation of this process..$^{2-7}$ Estrogens are produced by the irreversible aromatization of androgens promoted by $\mathrm{P} 450$ aromatase. These hormones need to bind their own nuclear or cell surface receptors to perform their cellular activity., ${ }^{3,8-10} \mathrm{P} 450$ aromatase is located in the cellular endoplasmic reticulum of testis and various other districts. ${ }^{10}$ In the testis, aromatase expression is regulated by cAMP through interaction of the gonad promoter with the transcription factor CREB (cAMP response element binding protein). ${ }^{11,12}$ In non-mammalian vertebrate testis, investigations on P450 aromatase have been conducted in different species as: the trout Oncorhynchus mykiss, ${ }^{13}$ the fish Anguilla anguilla, ${ }^{14}$ the frogs Xenopus laevis ${ }^{15}$ and Pelophylax esculenta,${ }^{16}$ and the reptile Podarcis sicula. ${ }^{5,17,18}$ In P. sicula testis, it has been shown that the P450 aromatase, as well as some testis local factors [pituitary adenylatecyclase-activating polypeptide (PACAP) and vasoactive intestinal peptide (VIP)], ${ }^{19-21}$ alters the balance between testosterone and $17 \beta$ estradiol levels, which acts as an on/off switch for spermatogenesis..$^{5,19-24}$ Investigations on P450 aromatase in mammalian testis are few. In particular, in rat testis the distribution pattern of aromatase changes during development: the enzyme is located within Sertoli cells in immature animals; instead, it is localized in Leydig and germ cells level in mature ones. ${ }^{9,25-27}$

Furthermore, also the investigations on the presence of P450 aromatase in epididymis are limited. In non-mammalians, as $P$. sicula, some investigations showed that inhibition of P450 aromatase by fadrozole changes the epididymal cell morphology. ${ }^{17}$ Moreover, the rat epididymal epithelial cells, as well as cell cultures of epididymis, showed the presence of $\mathrm{P} 450$ aromatase $m R N A .^{28,29}$

The aim of this work was to localize for the first time the aromatase in the vertebrate epididymis, as well as to compare how the distribution of this enzyme changes in the epididymis of two experimental models with different reproductive strategies. In particular, using immunohistochemical approach, our intention was to evaluate the presence of $\mathrm{P} 450$ aromatase in the epididymis of the seasonal breeder $P$. sicula and of the continuous breeder $R$. rattus which share the tubular organization of the testis. In Podarcis, the variation of the spermatogenic cycle during the different period of reproduction, not only change testis structure but also is associated with different epididymis organization. Specifically, epididymis epithelium during the reproductive period (May-June), is constituted of basal stem cells and columnar cells. The columnar cells present two nuclei and are quite active in the synthesis of large dense vacuoles that, once released their content in the epididymal lumen, take part in epididymal fluid organization. ${ }^{30-32}$ On the contrary, during the nonreproductive period (July-August), basal cells are still present, instead the columnar cells present a different morphology: they have a single nucleus and do not show the presence of large dense vacuoles indicating that they are not in active synthesis. Moreover, differently from what occurs during the reproductive period, spermatozoa are absent in the epididymis lumen during the non-reproductive period. ${ }^{31}$ Finally, during autumnal resumption (November-December), the epididymis epithelium presents a structure similar to the reproductive period, indeed are present the columnar cells in which are evident the secretion vacuoles; however these vacuoles are few compared to reproductive periods, as well as are few the spermatozoa evident in the lumen, because not useful for reproduction. ${ }^{30-32}$

Regarding rats, epididymis epithelium consists of four types of cells: basal, tight, main and apical cells. ${ }^{33-39}$ Basal cells are located on the basement membrane and do not interact with the epididymal lumen. This type of cells is responsible of the production of factors involved in immune responsivity, electrolytic secretion as well as regulation of main and tight cells activity. ${ }^{39}$ Tight cells present, around the nucleus, a thin cytoplasm with typical extensions projecting towards the lumen of the epididymis. ${ }^{38}$ The main cells have a large basal nucleus centrally located, and a well-developed secretion apparatus, which synthesizes proteins in the epididymal fluid. This synthesis apparatus is recognizable also in the apical cells, which, differently from the main cells, are not in contact with the basement membrane. ${ }^{38}$

More recently, in the epididymis of $P$. sicula, as well as $R$. rattus, we have demonstrated that VIP/VPACR system is widely represented, suggesting that such a system could play an active role in the reproduction of vertebrates, in particular sperm maturation and fertilization. ${ }^{40,41}$

Now, the present immunohistochemical investigation demonstrates that $\mathrm{P} 450$ aromatase is represented in the epididymis of both experimental models, suggesting that this protein complex could play an active role in vertebrate reproduction, mainly in sperm maturation and fertilization.

\section{Materials and Methods}

Male specimens of $P$. sicula lizards, sexually mature, were collected in Campania (southern Italy; Latitude: 41 19 ' 54 ' $\mathrm{N}$; Longitude: $13^{\circ}$ 59'29 'E) during reproductive period (May 2013), non-reproductive period (July 2013) and autumnal resumption (November 2013). After capture, the lizards were maintained in a soilfilled terrarium and fed ad libitum with Tenebrio molitor larvae, for approximately 15 days, the time required to reverse capture-related stress.

$R$. rattus epididymis of sexually mature animals, were kindly gifted by prof. M.P. Mollica, Department of Biology, Federico II University of Naples.

The experiments were permitted by institutional committee (Ministry of Health of the Italian Government) and organized to minimize the number of animals utilized for the experiments (6 animals for each species have been used).

After deep anesthesia with ketaminehydrochloride (325 pg/g of body mass; Parke-Davis, Berlin, Germany), animals were killed by decapitation and sexual maturity of each animal was determined using morphological parameters and histological analysis.

\section{Immunohistochemistry}

Paraffin-embedded Bouin's fixed testis with epididymis were cut at $5 \mu \mathrm{m}$ sections and used for immunohistochemistry analysis, as previously reported. ${ }^{42-49}$ Briefly, slides were dewaxed and heat treated in microwave $(2 \times 10 \mathrm{~min})$, using $0.1 \mathrm{M}$ citrate buffer $(\mathrm{pH}$ 6.0) for antigen retrieval. After washed in PBS, sections were first rinsed with $2.5 \% \mathrm{H}_{2} \mathrm{O}_{2}$ for $40 \mathrm{~min}$ to inactivate endogenous peroxidases and then blocked for $1 \mathrm{~h}$ with normal goat serum (Pierce, Rockford, IL, USA) to reduce non-specific background. Sections were incubated overnight at $4{ }^{\circ} \mathrm{C}$ with the primary antibody Rabbit anti-P450 aromatase (Santa Cruz Biotechnology, Santa Cruz, CA, USA), diluted 1:200 in normal goat serum and this antibody have been previously validated both in $P$. sicula ${ }^{5}$ and in $R$. rattus testis. ${ }^{46}$ The day after, the reaction was revealed with a biotin-conjugated goat anti-rabbit secondary antibody (Kit Pierce, diluted 1:2000 in normal goat serum) and an avidinbiotin-peroxidase complex (ABC immunoperoxidase Kit, Pierce), using diaminobenzidine (DAB) as chromogen. Sections were counterstained with Mayer's hematoxylin. Negative controls were performed by omitting incubation with primary antibody. Immunohistochemical signal was analyzed with Axioskop System (Zeiss, Oberkochen, Germany). 


\section{Results}

\section{Podarcis sicula}

P450 aromatase localization in epididymis during reproductive period

Immunohistochemistry analysis showed the presence of the enzyme P450 aromatase in the epididymis of the lizard $P$. sicula during the reproductive period. Specifically, P450 aromatase has been detected in both basal and columnar cells of the epididymis epithelium, in myoid cells, connective cells and in the spermatozoa present in the lumen (Figure 1 A-D). In particular, in columnar cells, the enzyme is localized in the cytoplasm and also in the large dense vacuoles present in the cytoplasm. Positive vacuoles for P450 aromatase were identified also in the epididymal lumen, where they were blended with labeled spermatozoa at level of acrosome and tail (Figure $1 \mathrm{~B}-\mathrm{D})$. In Figure 1E it is possible to note the absence of signal for P450 aromatase in the negative control.

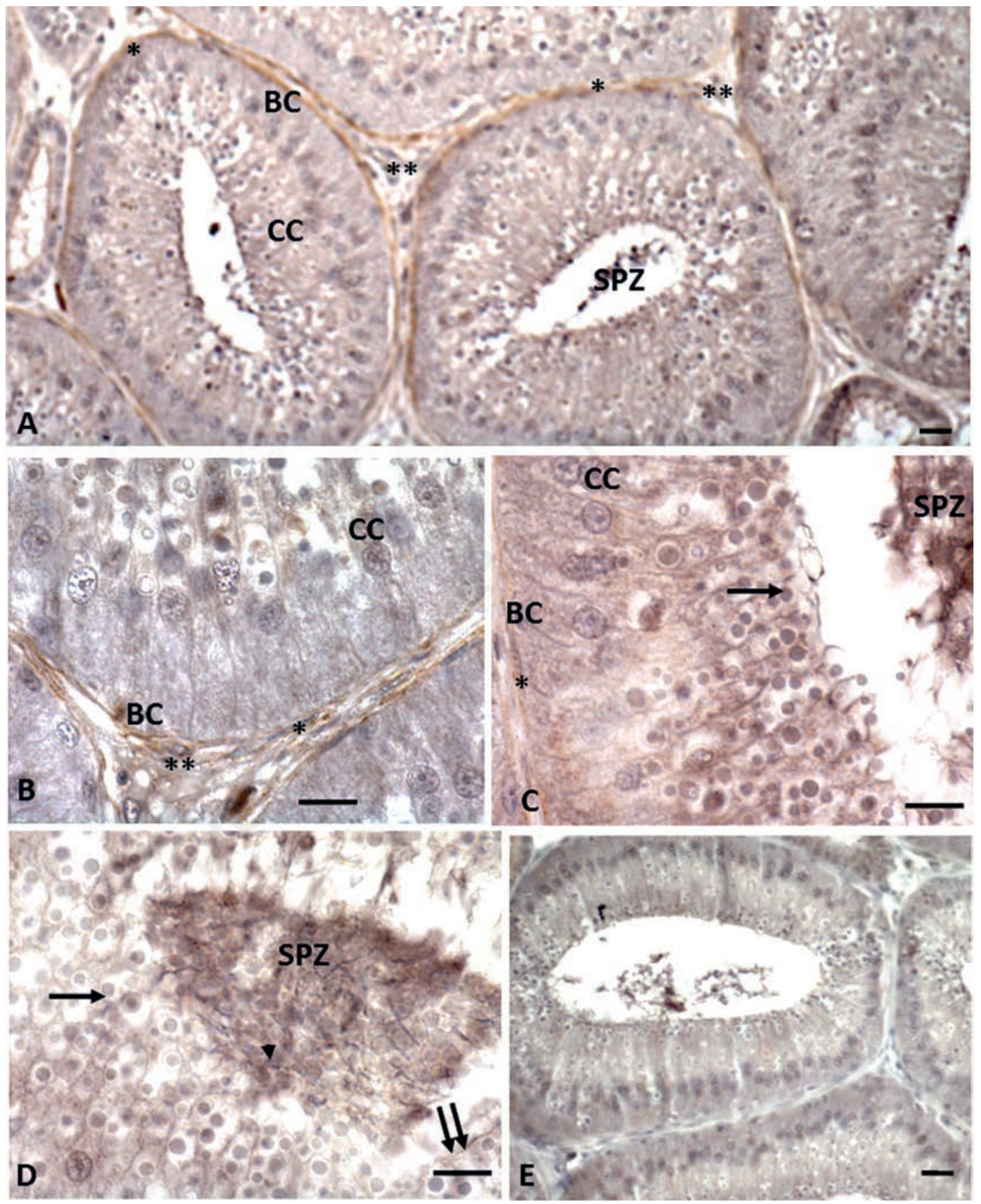

Figure 1. Reproductive period: immunohistochemistry for P450 aromatase in P. sicula epididymis. Immunolocalization signal appears as brown areas. A-B-C-D: a signal for P450 aromatase is evident in basal (BC) and columnar (CC) cells, as well as in myoid cells (asterisk) and connective cells (double asterisk). Spermatozoa (SPZ) present in the lumen are also immunolabelled: signal occurs in acrosome (arrowhead) and tail (double arrow). Signal is also evident in the large dense vacuoles present both in columnar cells and in epididymal lumen intermingled with spermatozoa (arrows). No signal is evident in the negative control sections (E). Scale bars: A,E) $20 \mu \mathrm{m}$; B,C,D) $5 \mu \mathrm{m}$. 
P450 aromatase localization in epididymis during non-reproductive period

During the non-reproductive period, P450 aromatase showed a more limited pattern of distribution in the epididymis of $P$. sicula. In fact, the signal was found only in myoid cells (Figure 2 A-C) while basal, columnar cells, as well as connective cells are not positive for $\mathrm{P} 450$ aromatase (Figure $2 \mathrm{~A}-\mathrm{C}$ ). Controls obtained by omitting the primary antibody showed no positive reaction (Figure 2D).

\section{P450 aromatase localization in epididymis during autumnal resumption}

During the autumnal resumption, immunohistochemistry performed with anti-P450 aromatase antibody, showed a similar distribution to reproductive period in lizard epididymis. In details, the immunohistochemical signal was evident within cytoplasm of columnar cells, as well as in few large dense vacuoles present in the cytoplasm and in the epididymal lumen, where they were intermingled with the spermatozoa, which result stained for P450
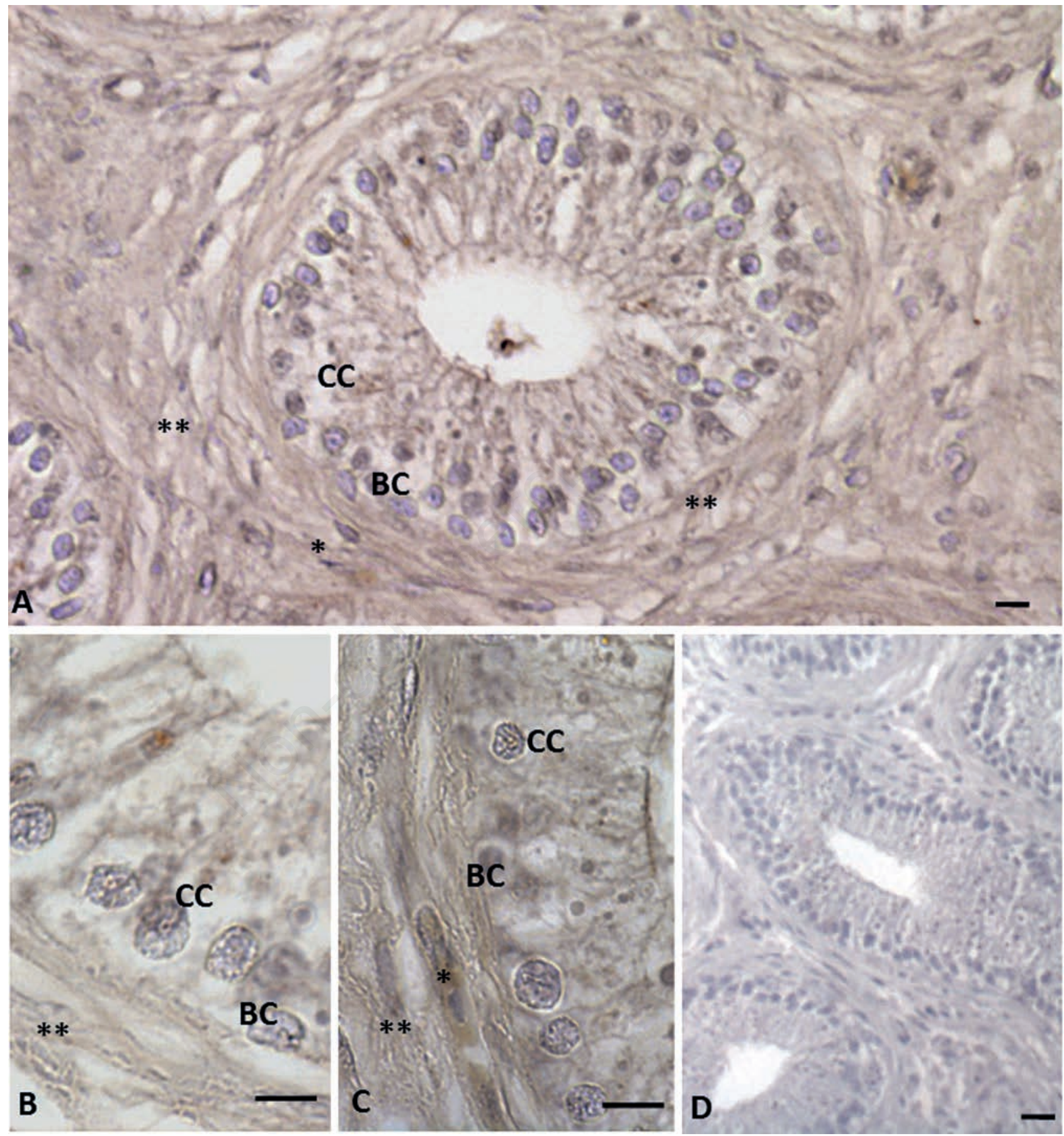

Figure 2. Non-reproductive period: immunohistochemistry for $\mathbf{P} 450$ aromatase in $P$. sicula epididymis. Immunolocalization signal appears as brown areas. A,B,C) Positivity for antibody is evident only in myoid cells (asterisk); no signal is evident in basal (BC) and columnar (CC) cells, as well as connective cells (double asterisk). D) Negative control section shows no signal. Scale bars: A,D) $20 \mu \mathrm{m}$; B,C) $5 \mu \mathrm{m}$. 
aromatase at both acrosome and tail (Figure 3 A-C). No signal occurred in epididymis cubic cells (Figure 3 A-B). In the spermatozoa, the signal was recognizable in both the acrosome and tail (Figure 3C). Immunolabelling for P450 was also observed in myoid cells; whereas no signal was evident in the connective tissue (Figure $3 \mathrm{~A}-\mathrm{B}$ ). Controls obtained by omitting the primary antibody were not immunolabelled (Figure 3C, insert).

\section{Rattus rattus}

\section{P450 aromatase localization in epididymis}

Immunohistochemistry performed for P450 aromatase in $R$. rattus epididymis showed absence of signal in basal, tight, main and apical epithelium cells (Figure 4 A-C); instead it was possible to highlight the signal in myoid and connective cells (Figure 4 A-C).

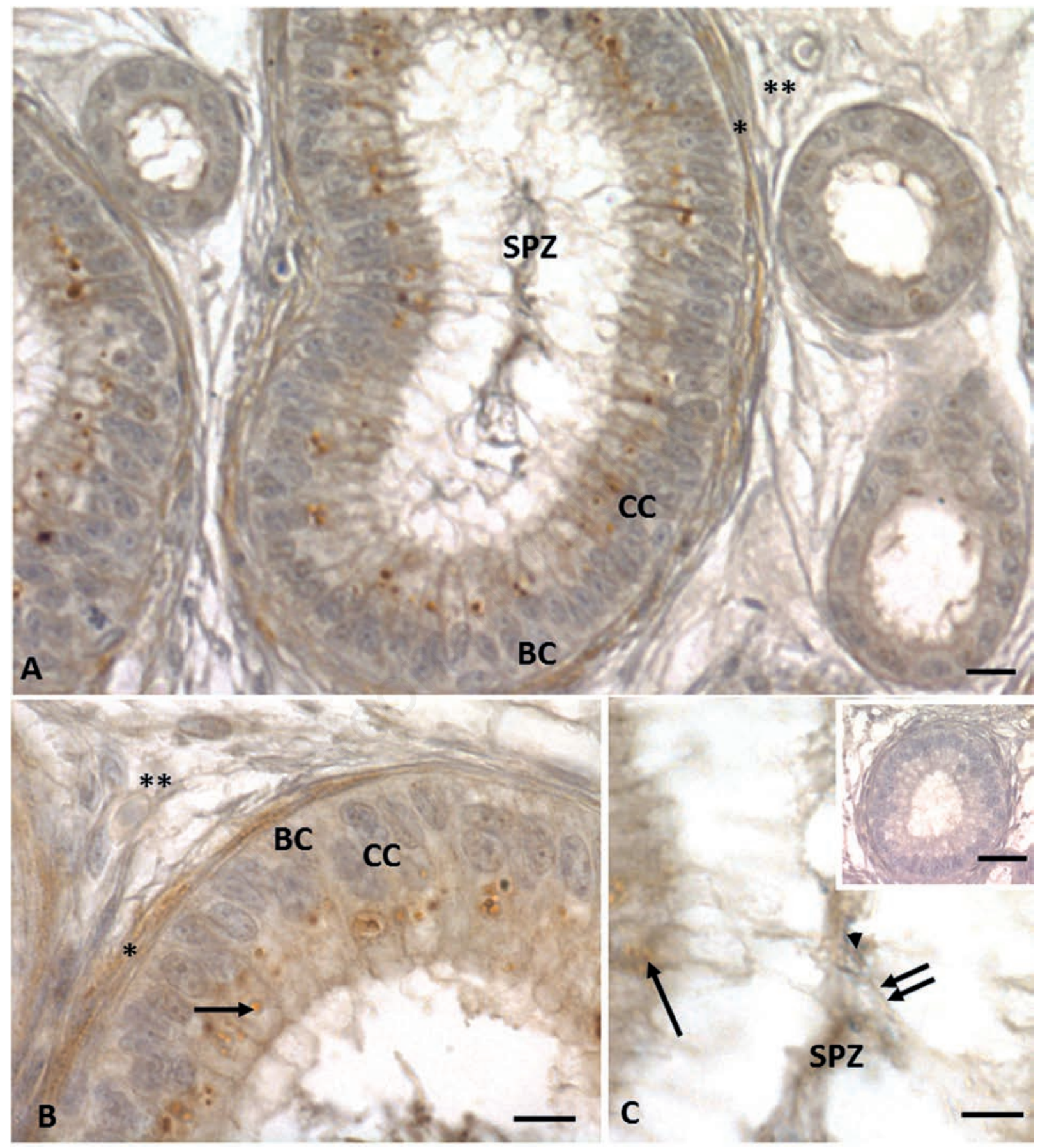

Figure 3. Autumnal resumption: immunohistochemistry for $\mathbf{P} 450$ aromatase in $P$. sicula epididymis. Immunolocalization signal appears as brown areas. A signal for $\mathrm{P} 450$ aromatase is evident in columnar (CC) cells, as well as in myoid cells (asterisk). No signal is evident in basal cells (BC) and connective cells (double asterisk). Spermatozoa (SPZ) present in the lumen are also immunolabelled: signal occurs in acrosome (arrowhead) and tail (double arrow). Signal is also evident in the large dense vacuoles present both in columnar cells and in epididymal lumen intermingled with spermatozoa (arrows). No signal is evident in the negative control sections. Scale bars: A,C insert) $20 \mu \mathrm{m}$; B,C) $5 \mu \mathrm{m}$. 
Moreover, P450 aromatase was detectable at the level of both acrosome and tail of the spermatozoa present within the epididymal lumen (Figure 4 A-B). Figure 4D shows negative controls.

\section{Discussion}

P450 aromatase is an enzyme involved in the synthesis of $17 \beta-$ estradiol, one the most relevant factors that locally control spermatogenesis. ${ }^{5,69,13,16,17}$ The aim of this paper was to assess the localization of $\mathrm{P} 450$ aromatase in the epididymis of two vertebrates with a different reproductive strategy and with tubular testis organization: $P$. sicula lizard and $R$. rattus, to highlight the possible role of this enzymatic complex in the control of reproduction. In $P$. sicula, it is well known the high titers of $17 \beta$-estradiol are responsible for spermatogenesis block, ${ }^{5,31}$ and that $\mathrm{P} 450$ aromatase acts as an on/off switch for spermatogenesis. ${ }^{5}$ In addition, in $P$. sicula, has been shown also that ERs mRNA are distributed in the
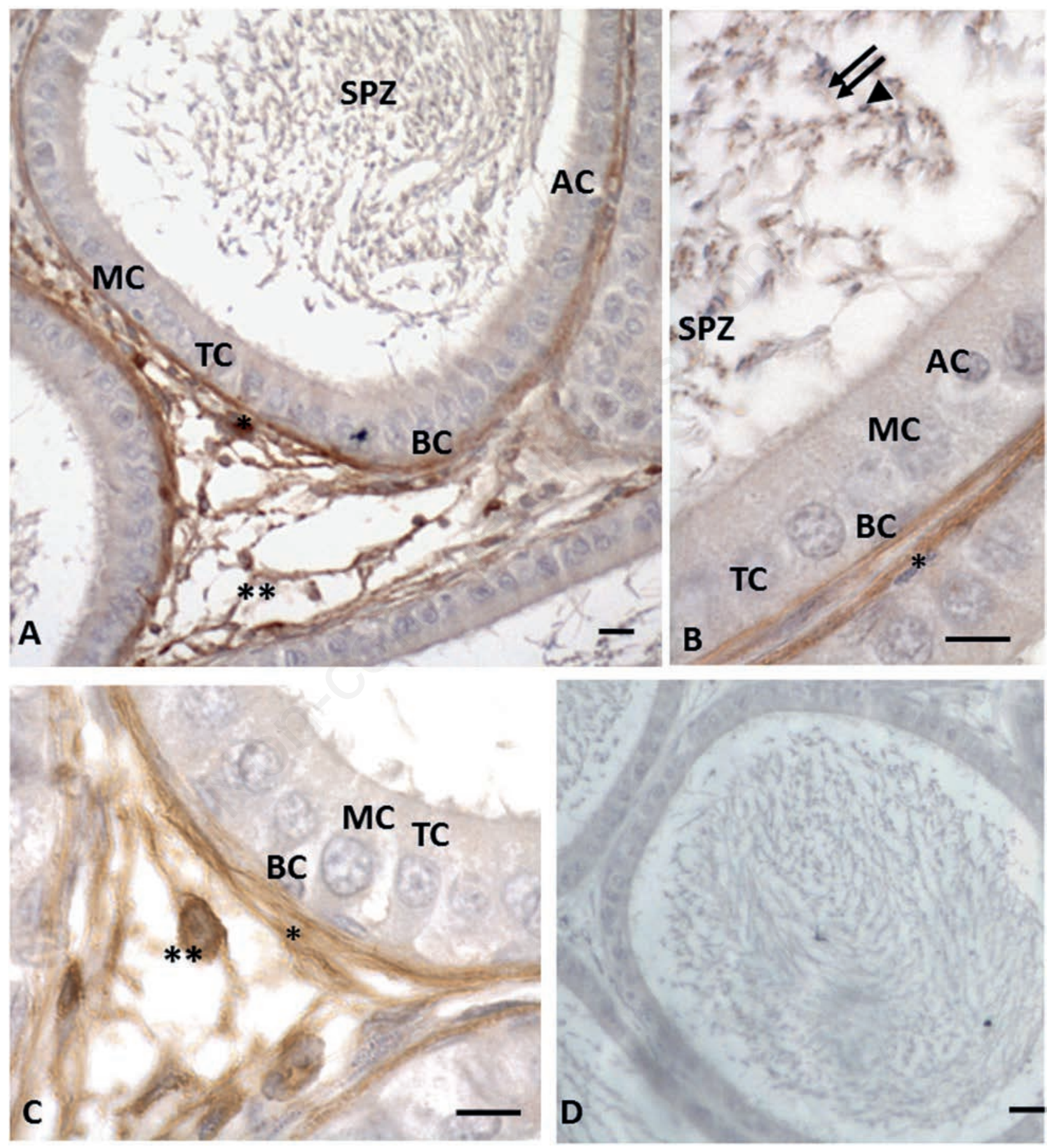

Figure 4. $R$. rattus epididymis: $\mathbf{P} 450$ aromatase immunolabelling appears as brown areas. A,B,C) Anti-P450 aromatase immunolabelling; no signal is evident in basal (BC), tight (TC), main (MC) and apical (AC) cells;. the positivity occurs in myoid cells (asterisk) and connective cells (double asterisk); the spermatozoa (SPZ) present in the lumen were immunolabelled: signal occurs in acrosome (arrowhead) and tail (double arrow). D) No signal is present in negative control sections. Scale bars: A,D) $20 \mu \mathrm{m}$; B,C) $5 \mu \mathrm{m}$. 
efferent duct and epididymis in all reproductive cycle. ${ }^{50}$ In $R$. rattus, it is well known that aromatase is present in somatic and germ cells of the testis and that estrogens are molecules involved in the spermio-histogenesis process. ${ }^{9}$ If on the one hand previous studies conducted in reptiles and rats have shown the presence of aromatase mRNA and estrogen receptors in the epididymis, no data are available so far about the localization of the $\mathrm{P} 450$ aromatase protein in this reproductive district.

In this study, we proved for the first time that $\mathrm{P} 450$ aromatase was well localized in the epididymis of two vertebrates: P. sicula, and $R$. rattus. We compared two experimental models that have different reproductive strategies; in particular, the use of $P$. sicula has allowed us to assess the epididymis activity in reproductive, non-reproductive and in autumnal resumption stages. Based on the function of the aromatase positive cells, our results suggest that this enzyme could be involved in different functions as sperm maturation, sperm progression and fertilization, as recently reported for PACAP and VIP. ${ }^{40,51,52}$ In details, an immunostaining for enzyme was found always in myoid cells and connective tissue as well as in acrosome and tail of spermatozoa present in the epididymal lumen.

The possible involvement of P450 aromatase in the sperm maturation stands out from the observations performed in P. sicula epididymis. In fact, a strong positivity for enzyme was reported also in the epithelial cells of epididymis during the reproductive period and autumnal resumption; during the non-reproductive period, the same positivity occurred only inside myoid cells. In particular, during the reproductive period, P450 aromatase labeling in the epithelial cells occurs within many large dense vacuoles, whose content is discharged into the lumen of epididymis where numerous spermatozoa are present. Thus, considering that $\mathrm{P} 450$ aromatase occurs both in cytoplasm and in large dense vacuoles present both in the columnar cells and in the lumen intermingled with spermatozoa, it could be hypothesized that the enzyme may contribute to sperm maturation. Moreover, the presence of P450 aromatase in spermatozoa, as previously reported in seminiferous tubules $^{5,9}$ strongly suggests that this enzyme could be involved in the acrosome biosynthesis and fertilization as reported for estrogens in rat and for PACAP and VIP in both experimental models. , $^{5,9,40,51}$ On the other hand, the P450 aromatase positivity evident in myoid cells, considering the function of these cells, could suggest that estrogens promote the release of cell content in the lumen of epididymis (sperm progression). Differently, in autumnal resumption, the presence of $\mathrm{P} 450$ aromatase in the cytoplasm of epididymis epithelial cells as well as and in large dense vacuoles, few compared to reproductive period, suggest that this enzyme could be involved in the resumption of epididymal activity, although in this period spermatozoa are few and not useful for reproduction. This spermatogenesis resumption is not useful for reproduction and its biological meaning could be linked to an evolutionary memory of a previous condition in which reptiles exhibited an annual bimodal reproduction. ${ }^{31}$

Furthermore, it is known that at level of efferent duct the expressions of Aquaporin 1-9 is under the control of estrogens, therefore the aromatase present in the spermatozoa could be involved in the control of water resorption from the seminal fluid as well as the secretion of $\mathrm{Cl}^{-}$ions, as demonstrated in other systems.$^{53}$ In fact, mice deficient in ER $\alpha$ are infertile because present at the level of epididymis a seminal fluid most diluted and less qualitative. ${ }^{54}$

Moreover, the different localization showed in P. sicula during the various moment of reproductive cycle, with more wide presence in the reproductive period, is in agreement with distribution of P450 aromatase in the male reproductive system showed in other seasonal breeders. ${ }^{55-58}$

Finally, the wider distribution of the enzyme in the epididymis of $P$. sicula compared to $R$. rattus, demonstrated that aromatase could play a key role in the control of structural and functional variations in the epididymis of a seasonal reproducer compared to a continuous reproducer. In fact, it is also possible to hypothesize that during the evolution, epididymis aromatase role has been reduced to advantage of other molecules, since in continuous reproducer the enzyme presents a more limited distribution.

In conclusion, P450 aromatase presence in $P$. sicula and $R$. rattus epididymis, strongly suggests that $17 \beta$-estradiol produced by enzyme could be involved in the control of reproduction, mainly in sperm maturation and fertilization, as well as in sperm mobility during the transfer across the epididymis.

\section{References}

1. Li M, Arimura A. Neuropeptides of the pituitary adenylate cyclase-activating polypeptide/vasoactive intestinal polypeptide/ growth hormone-releasing hormone/secretin family in testis. Endocrinol 2003;20:201-14.

2. O'Donell L, Robertson KM, Jones ME, Simpson ER. Estrogen and spermatogenesis. Endocr Rev 2001;22:289-318.

3. Carreau S, Silandre D, Bois C, Bouraima H, Galeraud-Denis I, Delalande C. Estrogens: a new player in spermatogenesis. Folia Histochem Cytobiol 2007;45:S5-10.

4. Del Giudice G, Prisco M, Agnese M, Verderame M, Rosati L, Limatola E, et al. Effects of nonylphenol on vitellogenin synthesis in adult males of the spotted ray Torpedo marmorata. J Fish Biol 2012;80:2112-21.

5. Rosati L, Agnese M, Di Fiore MM, Andreuccetti P, Prisco M. P450 aromatase: a key enzyme in the spermatogenesis of the Italian wall lizard Podarcis sicula. J Exp Biol 2016;219:2402-8.

6. Prisco M, Agnese M, De Marino A, Andreuccetti P, Rosati L. Spermatogenic cycle and steroidogenic control of spermatogenesis in Mytilus galloprovincialis collected in the gulf of Naples. Anat Rec 2017;300:1881-94.

7. Santillo A, Rosati L, Prisco M, Chieffi Baccari G, Andreuccetti P, Falvo S, et al. Aromatase immunolocalization and activity in the lizard's brain: Dynamic changes during the reproductive cycle. C R Biol 2019;342:18-26.

8. Carreau S, Papadopulos V, Drosdowsky MA. Stimulation of adult rat leydig cell aromatase activity by a Sertoli cell factor. Endocrinology 1988;122:1103-9.

9. Carreau S, Bouraima-Lelong H, Delalande, C. Estrogens: new players in spermatogenesis. Reprod Dev 2011;1:90-4.

10. Carreau S, Bourguiba S, Lambard S, Galeraud-Denis I, Genissel C, Bilinska B, et al. Aromatase expression in male germ cells. J Steroid Biochem Mol Biol 2001;79:203-8.

11. Lynch JP, Lala DS, Peluso JJ, Luo W, Parker KL, White BA. Steroidogenic factor 1 , an orphan nuclear receptor, regulates the expression of the rat aromatase gene in gonadal tissues. Mol Endocrinol 1993;7:776-86.

12. Carlone DL, Richards JS. Functional interactions, phosphorylation, and levels of $3^{\prime}, 5^{\prime}$-cyclic adenosine monophosphate-regulatory element binding protein and steroidogenic factor-1 mediate hormone-regulated and constitutive expression of aromatase in gonadal cells. Mol Endocrinol 1997;11:292-304.

13. Delalande C, Goupil AS, Lareyre JJ, Le Gac F. Differential expression patterns of three aromatase genes and of four estrogen receptors genes in the testes of trout (Oncorhynchus mykiss). Mol Reprod Dev 2015;82:694-708.

14. Peñaranda DS, Mazzeo I, Gallego V, Hildahl J, NourizadehLillabadi R, Pérez L, et al. The regulation of aromatase and androgen receptor expression during gonad development in 
male and female European eel. Reprod Domest Anim 2014;49:512-21.

15. Urbatzka R, Lutz I, Kloas W. Aromatase, steroid-5-alphareductase type 1 and type 2 mRNA expression in gonads and in brain of Xenopus laevis during ontogeny. Gen Comp Endocrinol. 2007;153:280-8.

16. Burrone L, Raucci F, Di Fiore MM. Steroidogenic gene expression following D-aspartate treatment in frog testis. Gen Comp Endocr 2012;175:109-17.

17. Cardone A, Comitato R, Bellini L, Angelini F. Effects of the aromatase inhibitor fadrozole on plasma sex steroid secretion, spermatogenesis and epididymis morphology in the lizard, Podarcis sicula. Mol Reprod Dev 2002;63:63-70.

18. Lance VA. Is regulation of aromatase expression in reptiles the key to understanding temperature-dependent sex determination? J Exp Zool A Ecol Genet Physiol 2009;311:314-22.

19. Rosati L, Prisco M, Coraggio F, Valiante S, Scudiero R, Laforgia V, et al. PACAP and PAC1 receptor in the reproductive cycle of male lizard Podarcis sicula. Gen Comp Endocr 2014;205:102-8.

20. Rosati L, Prisco M, Di Fiore MM, Santillo A, Sciarrillo R, Valiante S, et al. Sex steroid hormone secretion in the wall lizard Podarcis sicula testis: The involvement of VIP. J Exp Zool A Ecol Genet Physiol 2015;323:714-21.

21. Rosati L, Prisco M, Di Fiore MM, Santillo A, Valiante S, Andreuccetti P, et al. Role of PACAP on Testosterone and 17 $\beta$ estradiol production in the testis of wall lizard Podarcis sicula. Comp Biochem Physiol A Mol Integr Physiol 2016;191:180-6.

22. Agnese M, Rosati L, Prisco M, Coraggio F, Valiante S, Scudiero $\mathrm{R}$, et al. The VIP/VPACR system in the reproductive cycle of male lizard Podarcis sicula. Gen Comp Endocr 2014;205:94101.

23. Agnese M, Rosati L, Coraggio F, Valiante S, Prisco M. Molecular cloning of VIP and distribution of VIP/VPACR system in the testis of Podarcis sicula. J Exp Zool A Ecol Genet Physiol 2014;321:334-47.

24. Agnese M, Valiante S, Rosati L, Andreuccetti P, Prisco M. Pituitary Adenylate cyclase-Activating Peptide (PACAP) and PAC1 receptor in the testis of cartilaginous fish Torpedo marmorata: A molecular and phylogenetic study. Comp Biochem Physiol B Biochem Mol Biol 2016;191:26-35.

25. Bourguiba S, Genissel C, Lambard S, Bouraïma H, Carreau S. Regulation of aromatase gene expression in Leydig cells and germ cells. J Steroid Biochem Mol Biol 2003;86:335-43.

26. Carreau S. Estrogens-male hormones? Folia Histochem Cytobiol 2003;41:107-11.

27. Carreau S, Delalande C, Silandre D, Bourguiba S, Lambard S. Aromatase and estrogen receptors in male reproduction. Mol Cell Endocrinol 2006;246:65-8.

28. Wiszniewska B. Primary culture of the rat epididymal epithelial cells as a source of oestrogen. Andrologia 2002;34:180-7.

29. Shayu D, Rao AJ. Expression of functional aromatase in the epididymis: role of androgens and $\mathrm{LH}$ in modulation of expression and activity. Mol Cell Endocrinol 2006;249:40-50.

30. Galgano M, D'Amore C. [Il ciclo dell'epididimo in Lacerta s. sicula].[In Italian]. Istituto di Istologia ed Embriologia dell'Università Federico II di Napoli; 1960 Boll Zool 1960;27:1-20.

31. Angelini F, Botte V. Spermatogenesis in reptiles: dynamic and regulatory aspects. In: R Dallai, editor. Sex origin and evolution. Mucchi Selected Symposia and Monographs UZI, Modena, Italy; 1992; p. 211-23.

32. Verderame $M$. The involvement of the androgen receptor in the secretion of the epididymal corpus in the lizard Podarcis sicula. Int J Zool Res 2014;2014: 457830.

33. Cornwall GA, Lareyre JJ, Matusik RJ, Hinton BT, Orgebin-
Crist MC. Gene expression and epididymal function. In: B Robaire, BT Hinton, editors. The epididymis, from molecules to clinical practice. New York, Kluwer Academic/Plenum Publishers; 2002; p. 169-99.

34. Dacheux JL, Dacheux F. Protein secretion in the epididymis. In: B Robaire, BT Hinton, editors. The epididymis, from molecules to clinical practice. New York, Kluwer Academic/Plenum Publishers; 2002; p. 151-68.

35. Hermo L, Chong DL, Moffatt P, Sly WS, Waheed A, Smith CE. Region- and cell-specific differences in the distribution of carbonic anhydrases II, III, XII, and XIV in the adult rat epididymis. J Histochem Cytochem 2005;53:699-713.

36. Primiani M., G Mary, J Dufresne C E, Smith L, Lauren L, Bartles J R, et al. Microvillar size and espin expression in principal cells of the adult rat epididymis are regulated by androgens. J Androl 2007;28:659-69.

37. Robaire B, Hermo L. Efferent ducts, epididymis, and vas deferens: structure, functions, and their regulation. In: E Knobil, JD Neill, editors. The physiology of reproduction. New York, Raven Press; 1988; p. 999-1080.

38. Adamali HI, Hermo L. Apical and narrow cells are distinct cell types differing in their structure, distribution, and functions in the adult rat epididymis. J Androl 1996;17:208-22.

39. Veri JP, Hermo L, Robaire B. Immunocytochemical localization of the Yf subunit of glutathione S-transferase P shows regional variation in the staining of epithelial cells of the testis, efferent ducts, and epididymis of the male rat. J Androl 1993;14:23-44.

40. Rosati L, Andreuccetti P, Prisco M. Vasoactive intestinal peptide (VIP) localization in the epididymis of two vertebrate species. C R Biol 2017;340:379-85.

41. Rosati L, Santillo A, Di Fiore MM, Andreuccetti P, Prisco M. Testicular steroidogenic enzymes in the lizard Podarcis sicula during the spermatogenic cycle. C R Biol 2017;340:492-8.

42. Prisco M, Rosati L, Agnese M, Aceto S, Andreuccetti P, Valiante S. Pituitary adenylate cyclase-activating polypeptide in the testis of the quail Coturnix coturnix: Expression, localization, and phylogenetic analysis. Evol Dev 2019;218:145-56.

43. Agnese M, Rosati L, Muriano F, Valiante S, Laforgia V, Andreuccetti P, et al. Expression of VIP and its receptors in the testis of the spotted ray Torpedo marmorata (Risso1880). J Mol Neurosci 2012;48:638-46.

44. Agnese M, Verderame M, De Meo E, Prisco M, Rosati L, Limatola E, et al. A network system for vitellogenin synthesis in the mussel Mytilus galloprovincialis (L.). J Cell Physiol 2013;228:547-55.

45. Agnese M, Prisco M, Rosati L, Verderame M, De Meo E, Limatola E, et al. The synthesis of vitellogenin in the mussel Mytilus galloprovincialis: an interdisciplinary approach. In: J. Nowak, M Kozlowsk, editors. Mussels: Ecology, life habits and control. Nova Science Pub Inc. 2013; p. 1-13.

46. Rosati L, Agnese M, Abagnale L, Aniello F, Andreuccetti P, Prisco M. The Mussel Mytilus galloprovincialis in the Bay of Naples: New insights on oogenic cycle and its hormonal control. Anat Rec (Hoboken) 2019;302:1039-49.

47. Falvo S, Chieffi Baccaria G, Spaziano G, Rosati L, Venditti M, Di Fiore MM, et al. StAR protein and steroidogenic enzyme expressions in the rat Harderian gland. C R Biol 2018;341:160-6.

48. Motta CM, Tizzano M, Tagliafierro AM, Simoniello P, Panzuto R, Esposito L, et al. Biocide triclosan impairs byssus formation in marine mussels Mytilus galloprovincialis. Environ Pollut 2018;241:388-96.

49. Santillo A, Falvo S, Baccari GC, Di Giacomo Russo F, Rosati L, Di Fiore MM. Testis and brain steroidogenesis during the reproductive cycle of Pelophylax esculentus. In: L. Cannon, editor. Amphibians: Biology, ecology and conservation. Nova 
Science Pub Inc.; 2018; pp. 39-54.

50. Verderame M, Scudiero R. A comparative review on estrogen receptors in the reproductive male tract of non mammalian vertebrates. Steroids 2018;134:1-8.

51. Brubel R, Kiss P, Vincze A, Varga A, Varnagy A, Mark J, et al. Effects of pituitary adenylate cyclase activing polypeptide on human sperm motility. J Mol Neuroscien 2012;48:623-30.

52. Tanii I, Aradate T, Matsuda K, Komiya A, Fuse H. PACAPmediated sperm-cumulus cell interaction promotes fertilization. Reproduction 2011;141:163-71.

53. Hess RA. Estrogen in the adult male reproductive tract: a review. Reprod Biol Endocrinol 2003;9:1-52.

54. Ruz R, Gregory M, Smith CE, Cyr DG, Lubahn DB, Hess RA, et al. Expression of aquaporins in the efferent ductules, sperm counts, and sperm motility in estrogen receptor-alpha deficient mice fed lab chow versus casein. Mol Reprod Dev 2006;73:226-37.

55. Liu Q, Yu W, Fan S, Zhuang H, Han Y, Zhang H, et al. Seasonal expressions of androgen receptor, estrogen receptors, $5 \alpha$ - reductases and P450arom in the epididymis of the male muskrat (Ondatra zibethicus). J Steroid Biochem Mol Biol 2019;194: 105433.

56. Wang J, Liu Q, Qi H, Wang Y, Gao Q, Gao F, et al. Seasonal expressions of androgen receptor, P450arom and estrogen receptors in the epididymis of the wild ground squirrel (Citellus dauricus Brandt). Gen Comp Endocrinol 2019;270:131-8.

57. Li Q, Zhang F, Zhang S, Sheng X, Han X, Weng Q, et al. Seasonal expression of androgen receptor, aromatase, and estrogen receptor alpha and beta in the testis of the wild ground squirrel (Citellus dauricus Brandt). Eur J Histochem 2015;59:2456.

58. Wang Y, Wang Z, Yu W, Sheng X, Zhang H, Han Y, et al. Seasonal expressions of androgen receptor, estrogen receptors and cytochrome P450 aromatase in the uteri of the wild Daurian ground squirrels (Spermophilus dauricus). Eur J Histochem 2018;62:2889.

Received for publication: 6 November 2019. Accepted for publication: 8 January 2020 .

This work is licensed under a Creative Commons Attribution-NonCommercial 4.0 International License (CC BY-NC 4.0).

(C) Copyright: the Author(s), 2020

Licensee PAGEPress, Italy

European Journal of Histochemistry 2020; 64:3080

doi:10.4081/ejh.2020.3080 